\title{
Mariano Bertuchi como pintor de la intimidad marroquí
}

\author{
Belén Abad de los Santos \\ Universidad de Sevilla
}

Título: Mariano Bertuchi como pintor de la intimidad marroquí.

Resumen: Este artículo tiene como objetivo recuperar la figura del artista granadino Mariano Bertuchi Nieto (1884-1955), uno de los pintores decisivos en la construcción de imágenes en el contexto africanista de la primera mitad del siglo XX. Considerado por antonomasia "el pintor oficial del Protectorado español en Marruecos", habría de materializar su proyecto comunicativo de forma exhaustiva a través de diversos soportes expresivos: carteles de turismo, series de sellos, postales, ilustraciones para revistas y libros, $y$, en sentido estricto, obras pictóricas. Lejos de centrarse en la pintura de corte oficialista salida de sus pinceles, en este artículo se abordan sus comunicaciones plásticas de cariz más intimista, indagando sobre las posibles conexiones entre la literatura colonial de la época y una selección de la producción de Bertuchi durante la década de los Cuarenta.

Palabras clave: Mariano Bertuchi, Marruecos, Protectorado, Africanismo, Pintura.

Fecha de recepción: 25/9/2016.

Fecha de aceptación: 22/11/2016.
Title: Mariano Bertuchi as a Painter of Moroccan Privacy.

Abstract: This article aims to recover the figure of the artist from Granada Mariano Bertuchi Nieto (1884-1955), one of the decisive painters in the construction of images in the africanist context of the first half of the twentieth century. Considered by antonomasia "the official painter of the spanish Protectorate in Morocco", would have to materialize his communicative project in a comprehensive way through various expressive supports: tourism posters, series of stamps, postcards, illustrations for magazines and books, and, strictly speaking, pictorial works. Far from focusing on the officialist painting made by the artist, this article addressed his more intimate plastic communications. In the analysis carried out, one investigates the possible connections between the colonial literature of the time and a selection of the Bertuchi's production developed across the Forties.

Key words: Mariano Bertuchi, Morocco, Protectorate, Adricanism, Painting.

Date of Receipt: 25/9/2016.

Date of Approval: 22/11/2016. 


\section{LAS COSTURAS DEL TIEMPO}

La presencia española en Marruecos a partir de la segunda mitad del siglo XIX, a raíz del conflicto bélico (1859-1860) entre ambos países, transfiguró, en palabras de Arnavat, "el orientalismo andalusí de los románticos — es decir, el Oriente musulmán dentro de la Península Ibérica — en un africanismo marroquinista, confiriéndole una pátina colonial específica" ${ }^{\text {. }}$ En este sentido, Morales Lezcano evidencia acertadamente que al considerarse la Península Ibérica un territorio bisagra entre dos continentes, Marruecos ha retornado a los africanistas españoles "la imagen caleidoscópica” de una civilización generada por múltiples estratos etno-culturales heredados — bereber, romano, árabe-musulmán, morisco, judío, sefardita, etc. - . La imagen ha tenido sus resonancias, supliendo durante varias generaciones un espacio inexistente dentro "de un orientalismo a la anglo-francesa imposible de generar en las circunstancias reinantes dentro de la Península Ibérica en el siglo XIX”2. El mismo autor, en su libro Africanismo y orientalismo en el siglo XIX, considera que "el Africanismo español, centrado en Marruecos, fue así un sucedáneo específico del orientalismo europeo"3.

De este modo, diversas disciplinas artísticas, como la literatura, la pintura, la música, la ilustración gráfica, la arquitectura, la fotografía y el cine hispanos, han tenido por objeto de estudio y motivo de inspiración las realidades descubiertas en el Imperio de Marruecos. Así pues, "el norte de África fue para España su Oriente musulmán, razón por la cual el orientalismo hispano fue africanista en su plasmación, et pour cause" .

1 Albert Arnavat, "Cataluña y Marruecos en el siglo XIX. Visiones de historia cultural”, en Visiones del Al-Maghrib. Pintores catalanes ochocentistas, ed. Jordi À. Carbonell, Cataluña, Instituto Catalán del Mediterráneo et alt., 2001, pp. 27-53 (pp. 33-34).

2 Víctor Morales Lezcano, "Especificidad del Orientalismo Español", Awraq, anejo a XI (1990), pp. 17-35 (p. 30).

3 Víctor Morales Lezcano, Africanismo y orientalismo en el siglo XIX, Madrid, UNED, 1989, pp. 12-14.

4 Ibidem, p. 139. 
También debe señalarse que la guerra hispano-marroquí habría de transformar la visión que del mundo magrebí tenían nuestros pintores, a raíz del contacto directo producido por sus continuos viajes al territorio norteafricano. Carbonell subraya el gran número de manifestaciones culturales etnocéntricas y colonialistas producidas por dicha contienda, la cual significó para algunos intelectuales enfrentarse a una realidad que hasta ese momento sólo conocían a través de relatos de exotismo o fantasías orientales románticas 5 .

Carbonell ${ }^{6}$ detalla el viaje del pintor catalán Marià Fortuny (18381874), con motivo del encargo de la Diputación de Barcelona, al objeto de inmortalizar pictóricamente las gestas del batallón de voluntarios catalanes en Marruecos, como el inicio de lo que Morales Lezcano ha denominado "africanismo pictórico", es decir, la pintura española de tema magrebí. Sobre la presencia de Marruecos en la pintura peninsular, Mesari ${ }^{7}$ establece tres etapas bien diferenciadas. La primera — pintura de la guerra de África (1859-1860) — y la segunda — pintura de post-guerra (último tercio del siglo XIX y primera década del XX), se caracterizan por su naturaleza romántico-orientalista; mientras que una tercera etapa, de naturaleza impresionista, se correspondería con la época del Protectorado, aunque este período se reduce a unos pocos nombres destacados que se suceden históricamente: Marià Fortuny (Reus 1838 -Roma 1874), Josep Tapiró (Reus 1836-Tánger 1913) y Mariano Bertuchi (Granada 1884 - Tetuán 1955).

De esta forma, Mariano Bertuchi viene a clausurar la nómina, significativamente iniciada por Marià Fortuny, de un compendio de pintores a quienes Marruecos fascinó y resultó decisivo para la evolución de sus manifestaciones artísticas ${ }^{8}$.

5 Jordi Á. Carbonell, "Visiones del Magreb en la pintura catalana decimonónica", en Visiones del Al-Maghrib. Pintores catalanes ochocentistas, ed. Jordi À. Carbonell, Cataluña, Instituto Catalán del Mediterráneo et alt., 2001, pp. 55-87 (p. 63).

6 Ibidem, p. 62.

7 Ibidem, p. 82.

8 Eduardo Dizy, "Bertuchi, maestro de artesanos y artistas. Fidelidad a un patrimonio histórico", en Mariano Bertuchi. Pintor de Marruecos, Barcelona, Lunwerg Editores, 2000, pp. 103-115. 


\section{2. ÁFRICA ¿CUÁNDO Y POR QUÉ?: APUNTES BIOGRÁFICOS}

Mariano Bertuchi Nieto (1884-1955), granadino de nacimiento y tetuaní de adopción, vivió a caballo entre el siglo XIX y el XX. Fue el pintor por excelencia del Protectorado español en Marruecos (1912-1956), entre otras razones porque su ciclo vital en esas tierras coincide precisamente con el período cronológico de su desarrollo y, luego, por sus propias peculiaridades profesionales, artísticas y humanas.

Nació en el seno de una familia acomodada con ciertas inquietudes intelectuales, que supo estimular sus aptitudes artísticas desde temprana edad. Estudiosos como Bermudo Soriano o Gómez Barceló ${ }^{9}$ ofrecen datos que apuntan a un retrato de niño prodigio revelador de la precocidad del joven Mariano, el cual, cuando sólo contaba doce años de edad, fue nombrado Socio de Honor del Liceo Artístico y Literario de su ciudad natal gracias a su cuadro La Adoración de la Cruz por Isabel la Católica ${ }^{10}$. En esa época infantil, que transcurre en Andalucía, y más concretamente entre Granada y Málaga — ciudades con un marcado refinamiento árabe-, pronto se despertaría en él un especial interés por Marruecos.

Utande Ramiro y Utande Igualada ${ }^{11}$ subrayan una cuestión fundamental en la vida de Mariano Bertuchi: “África, ¿cuándo y por qué?”. Algunas crónicas afirman que, con celeridad, sintió, al igual que otro ilustre granadino, Pedro Antonio de Alarcón (1833-1891), "la llamada africana". Esa "especie de ley migratoria", a la que hace mención Bermejo — seguida también por Fortuny y Tapiró—, habría de orientar sus pasos hacia el septentrión africano. García Figueras denominó a este impulso hacia Marruecos su "vocación africana"12. El pintor cruzó el Estrecho por vez primera en el año 1898, donde, en compañía de un cicerone eminente, el arabista Aníbal Rinaldi (1829-1923), conoció Tánger.

9 José Luis Gómez Barceló, "Mariano Bertuchi Nieto: ilustraciones”, Cuadernos del Rebellin, Ceuta, 6 (1992), p. 11.

10 Eliseo Bermudo Soriano, "Apuntes mecanografiados del libro inédito", en Españoles en África, 1945, p. 2 (Documento inédito).

11 María del Carmen Utande Ramiro y Manuel Utande Igualada, "Mariano Bertuchi y sus dibujos de la Guerra Civil Marroquí (1903-1908) en el Museo de la Academia”, Boletín de la Real Academia de Bellas Artes de San Fernando, 75 (1992), pp. 321-368 (p. 326).

12 José Bermejo, Homenaje en Granada. Exposición en el Corral del Carbón, 1956, p. 2 (Documento inédito). 
De este modo, su fascinación marroquí se transformará en una constante en el decurso vital de Bertuchi. Sus continuas visitas al norte de África serán prolongadas en el tiempo, hasta afianzarse finalmente en Tetuán. El propio pintor lo declararía a Bermudo Soriano con estas palabras: "Más tarde, aprovechando todos los asuetos, yo tendría que visitar muchas veces Marruecos, atraído por su color y sus encantos. Muchas veces, sí, hasta quedar anclado definitivamente, en este bello y pintoresco país" ${ }^{13}$.

En la línea pictórica, continuadora de su admirado Fortuny, fomentada por lo que había visto en Marruecos, arranca una etapa de escenas orientales, y expone sus pinturas orientalistas en certámenes granadinos a finales del siglo XIX. Fruto de su estancia en Marruecos fueron las obras que presentó en el Corpus granadino de 1899: Contando un cuento, El zoco de Tánger y Mercado de frutas, además de La procesión del Cristo de la Luz y Apunte. Asimismo, ese año pintaría un lienzo de gran formato $(100 \times 150 \mathrm{~cm}$.) titulado El Cheriff de Uazzán — reproducido en la revista Mauritania - , con escenas marcadamente historicistas y orientalistas, que denotan la influencia del citado Fortuny ${ }^{14}$.

Sus progenitores, conscientes de la verdadera vocación de su hijo por la pintura, deciden, aun careciendo Bertuchi de la edad suficiente para ingresar en la Escuela de Bellas Artes de Granada, llevarlo al estudio del maestro Eduardo García Guerra (1827-1893) y, posteriormente, al de José de Larrocha (1850-1933), discípulo de Carlos de Haes (1826-1898), uno de los ilustres artistas que revolucionó el paisajismo del siglo XIX español.

En 1892, Bertuchi inicia su formación académica en Málaga, a donde se traslada muy joven, teniendo allí como maestros a Bernardo Ferrándiz (1835-1895) y Martínez de la Vega (1846-1905). Sobre su etapa de aprendizaje artístico en la ciudad costera, Díaz Bresca apunta que a los ocho años de edad ingresó en la Escuela de Bellas Artes de Málaga —en las clases de figura, marina y paisaje-, obteniendo el pase a la clase del antiguo, colorido y composición ${ }^{15}$.

13 Eliseo Bermudo Soriano, op. cit., p. 3.

14 José Antonio Pleguezuelos, Mariano Bertuchi y San Roque, Cádiz, Fundación de Cultura Lis Ortega Bru y Ayuntamiento de San Roque, 2007, pp. 33-35.

15 Antonio Díaz Bresca, "Mariano Bertuchi", La Unión Mercantil, XXIII (16/ 
En esta época vinculada a Málaga, tomará contacto con la obra de Antonio Muñoz Degrain (1840 - 1924), con el que coincidirá durante su periodo universitario de Madrid (1899 - 1904), llegando a convertirse en su discípulo. Será Degrain el que, al acceder a la dirección del Círculo de Bellas Artes de Madrid, lo patrocine y presente en sociedad en las exposiciones del Círculo ${ }^{16}$. Sin embargo, finalizado el primer curso en la capital, en 1900 se tiene constancia de un nuevo viaje a Tánger. Resultado de su peregrinaje por tierras norteafricanas serán las obras Moros y Una calle en Tánger, que formarían parte de la exposición de Bellas Artes y Decorativas organizada por el Liceo Artístico y Literario de Granada en 1901.

Finalizados sus estudios académicos en 1904, el pintor africanista fue aproximándose paulatinamente a Marruecos, residiendo primero en San Roque (1911-1918), después en Ceuta (1918-1928) —donde se instalaría con su esposa, Esperanza Brotons y su hijo Fernando-y, finalmente, en Tetuán (1928-1955). En esta ciudad fijó su residencia hacia 1928, desempeñando el cargo de Inspector Jefe de los Servicios de Bellas Artes en el Protectorado Español.

Durante su época marroquí, Bertuchi no sólo desarrolló su producción artística como pintor y diseñador gráfico, abordando asimismo las vertientes del diseño publicitario, editorial y filatélico, sino que emprendió una labor didáctica. En 1930 fue nombrado director de la Escuela de Artes Marroquíes de Tetuán, donde lideraría un proyecto de renovación pedagógica en sus talleres. Estas aspiraciones educativas culminaron con la creación de la Escuela Preparatoria de Bellas Artes en 1945. Del mismo modo, en su afán por la conservación y el fomento del patrimonio marroquí, fundó el Museo Marroquí (1948). Igualmente, colaboró con innumerables entidades e instituciones catalizadoras de ese gran proyecto colonial que constituyó el Protectorado español en Marruecos.

Bertuchi, a pesar de haber alcanzado un extraordinario renombre en su tiempo como puente transmisor entre dos culturas, tras su fallecimiento se desvaneció en el olvido. Probablemente haya sido su vinculación con

III/1908).

16 María Dolores Santos, "Mariano Bertuchi Nieto, de Granada a Tetuán", en Mariano Bertuchi, pintor de Marruecos, pp. 55-71 (p. 60). 
el régimen franquista el principal motivo del mutismo sobre su figura y producción, en las obras que relatan la historia del arte español del siglo XX, en donde, como evidencian los Utande "resulta virtualmente ignorado" 17 . No puede olvidarse que los medios de propaganda gubernamentales aprovecharon la sugestiva visión plástica de Marruecos delineada por el artista como un "magnífico altavoz" ${ }^{18}$ para proyectar la labor de España en el Protectorado — no sólo en la metrópoli sino también en el extranjero-.

Este artículo pretende colmar el desdén que hoy se cierne sobre el granadino, sin duda una de las personalidades más inexploradas en el ámbito artístico de la primera mitad del Novecientos y figura clave dentro del contexto orientalista o africanista.

\section{Los paisajes interiores de Bertuchi}

Mariano Bertuchi, durante su dilatada vida en tierras norteafricanas, compuso en sus obras artísticas la crónica oficial del Protectorado español en Marruecos; no obstante, al mismo tiempo, captó también la esencia cotidiana del pueblo marroquí. En las múltiples disciplinas que cultivó en el círculo de las Bellas Artes — pintor, ilustrador, director artístico de la revista África, diseñador filatélico, cartelista-, el artista granadino cristalizó en imágenes las más variadas y evocadoras estampas del norte de Marruecos. En las diversas vistas de ciudades y paisajes, en donde el elemento humano siempre se convierte en el eje vertebrador de la escena, Bertuchi reflejó las secuencias costumbristas de zocos, callejones, fondacs o ritos populares, siendo el notario de la vida privada de los marroquíes en un territorio tutelado por España. Estos espacios escénicos norteafricanos conformarán globalmente el peculiar universo visual del pintor, donde lugares y tradiciones quedarán almacenados a modo de fugaces fotogramas, actuando como "dispositivos catalizadores" del imaginario colonial español de Marruecos.

17 Ma del Carmen Utande Ramiro y Manuel Utande Igualada, op. cit., p. 328.

18 Enrique Arias Anglés, "Mariano Bertuchi, pintor del Protectorado", en El Protectorado español en Marruecos. La historia trascendida, eds. Manuel Gahete Jurado y Fatiha Benlabbah, Bilbao, Iberdrola, 2013, pp. 72-76 (p. 73). 
Vallina observa que el pintor africanista desarrollará no sólo "obra de encargo, ya sean retratos o reconstrucciones históricas de hechos militares", sino también plasmará en sus lienzos "la intimidad del rostro anónimo" ${ }^{19}$. Asimismo, Bertuchi es denominado, por los temas de sus escenografías pictóricas, en palabras de Capelastegui, como un paisajista urbano, "eligiendo la calle como el motivo más frecuente [...], recreándose en la blanca geometría de los edificios y recortando las siluetas de los marroquíes en la cotidiana ociosidad de sus siestas o en sus pausados y cadenciosos movimientos" ${ }^{20}$. En efecto, en la obra de Bertuchi, el pintor mostrará la vida ciudadana tetuaní (Figs. 1-4) como asunto constante, evidenciado con tino por Capelastegui en las líneas que siguen:

La calle y sus transformaciones: tranquila y sosegada a distintas horas del día, y con sus variaciones lumínicas, a pleno sol, al atardecer... La calle trasformada en rito solemne cuando el Jalifa se desplaza del palacio a la mezquita y, de pronto, la actividad se paraliza para, respetuosamente, rendir homenaje al que, erigido desde un poder superior le presiente bajo su sombrilla. La calle en su plenitud, transformada en espectáculo comercial: el zoco. El bullicio, el color y el ajetreo de los mercachifles se concentran en un lugar concreto, en un día determinado y acuden desde kilómetro a la redonda. Desde el panorama elevado, la feria multicolor, con el pequeño puesto de calzado o alimentos junto al encantador de serpientes o músico ambulante, constituye un elemento polifacético irrepetible ${ }^{21}$.

19 Sonsoles Vallina, "La pintura de Bertuchi. Un diario personal de luz y color", en Mariano Bertuchi, pintor de Marruecos, pp. 73-81 (p.73).

20 Pilar Capelastegui, "Mariano Bertuchi y el paisaje marroquî", Goya. Revista de Arte, 205-206 (1988), pp. 68-75 (p. 72).

21 Ibidem, p. 73. 

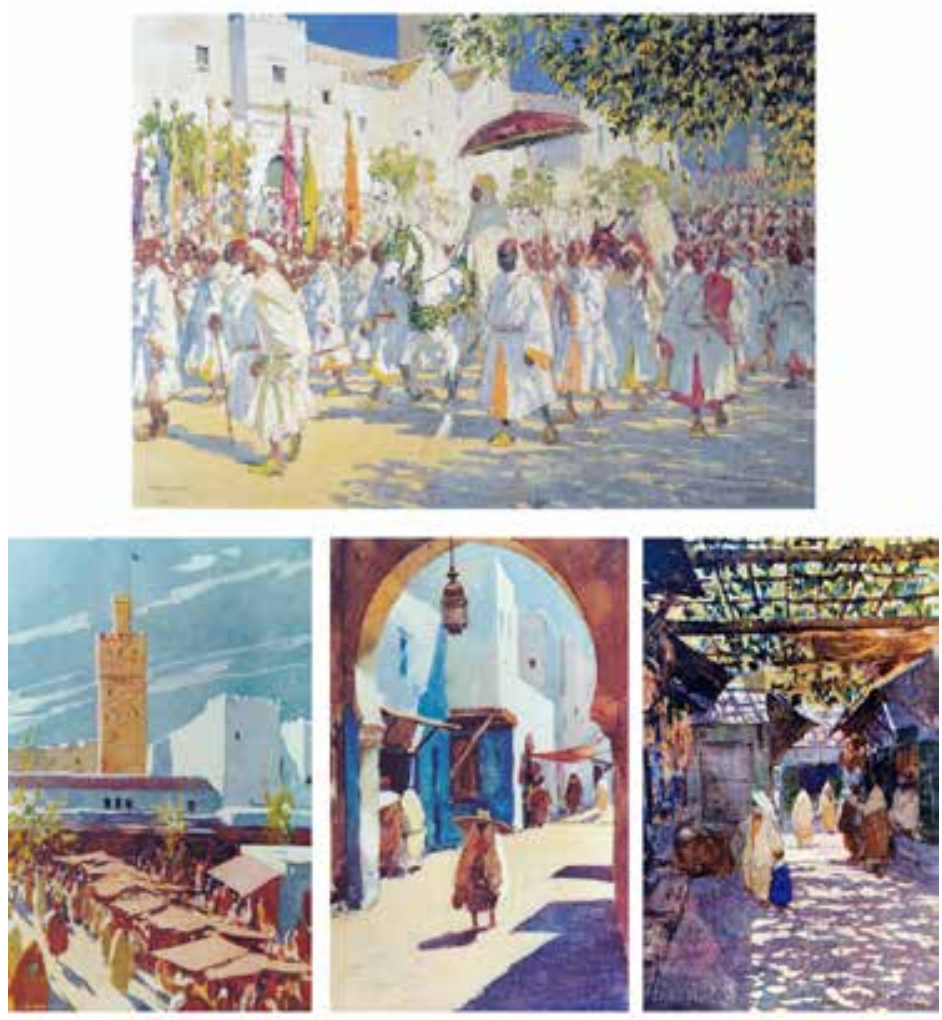

Figs. 1-4.

Sin embargo, el hilo discursivo de la obra bertuchiana, como se ha señalado previamente, girará en torno a las gentes de Marruecos, bien habitando las escenas asiduas del contexto como sujetos que adoptan "el rol del personaje"22, bien como simples espectadores figurantes del filme colonial. En dicho instante, como relata José Abad,

ellos serán los protagonistas que entren y salgan, con sus escenas cotidianas, por las omnipresentes puertas que dan acceso a la ciudad, de Fez, de Tánger, de la Luneta, de la Reina, de Saida, del Yiaf, la de Makaber o de los cementerios... con el fin de crear una simbiosis entre Bertuchi y la motivaciones surgidas.

22 Lorenzo Vilches, La lectura de la imagen, Barcelona, Paidós, 1995, p. 141. 
Desde ese momento, todo ese mundo penetra por las ventanas de su estudio, y permanece allí, en su espíritu marroquí, hasta hacerle descubrir "que lo que no se publicita no existe"23.

Del mismo modo, la consideración de Bertuchi como paisajista de interiores podría estar justificada en función de una selección de obras pictóricas. Si se efectúa un análisis más detallado dentro de su repertorio pictórico, localizamos una sucesión de óleos pintados en la década de 1940, cuya temática se condensa precisamente en la recreación de espacios íntimos donde los personajes-actores se funden como coprotagonistas junto a las escenografías tetuaníes de patios interiores, jardines, azoteas o terrazas a modo de decorados de teatro. Lejos de centrarse en la pintura de corte oficialista bertuchiana, en este artículo se abordan sus expresiones plásticas de cariz más intimista.

Cronológicamente, la primera pintura objeto del presente trabajo es La Terraza (Fig. 5), óleo sobre tabla $(79 \times 63 \mathrm{~cm}$.), fechado en 1942, cuya escenografía tiene por ambiente un fragmento de una terraza de la Escuela de Artes y Oficios de Tetuán. En esta tela se aprecia el ir y venir de sombras y luces, la calma superficie del suelo y el lenguaje silencioso de los ornamentos que componen el mundo privado de la mujer marroquí. Bertuchi omite lo que podría determinar nuestra atención en el primer plano y enfoca la enigmática figura femenina en plano medio, cuya silueta de espaldas queda enmarcada por uno de los dos arcos de medio punto que conforman la moldura de la puerta de entrada a la galería. La mirada del espectador se dirige irremediablemente hasta el plano intermedio, donde, en la profundidad, se definen los correspondientes detalles de un espacio exterior: el balcón mirador, como si de otra habitación se tratara, ejerce de improvisado refugio íntimo para la protagonista. La mujer, ataviada con el peculiar edfin $n^{24}$ de color blanco de zinc, y cubierta su cabeza con un pańuelo en tonos amarillo medio y ocre de Nápoles, se encuentra apoyada sobre la balaustrada. En actitud contemplativa y de natural reposo, acorde con la atmósfera entre sensorial y melancólica, donde parece desfilar a la vez el tiempo y el recuerdo, nuestra protagonista se muestra

23 José Abad, "Tres secuencias comunicativas en Bertuchi”, en Mariano Bertuchi, pintor de Marruecos, pp. 93-101 (p. 96).

24 Túnica muy fina que se viste sobre el caftán. 
ajena, tal vez, a la inesperada mirada del espectador. La escena invita a la reflexión, resultando casi imposible no imaginar la presencia del pintor.
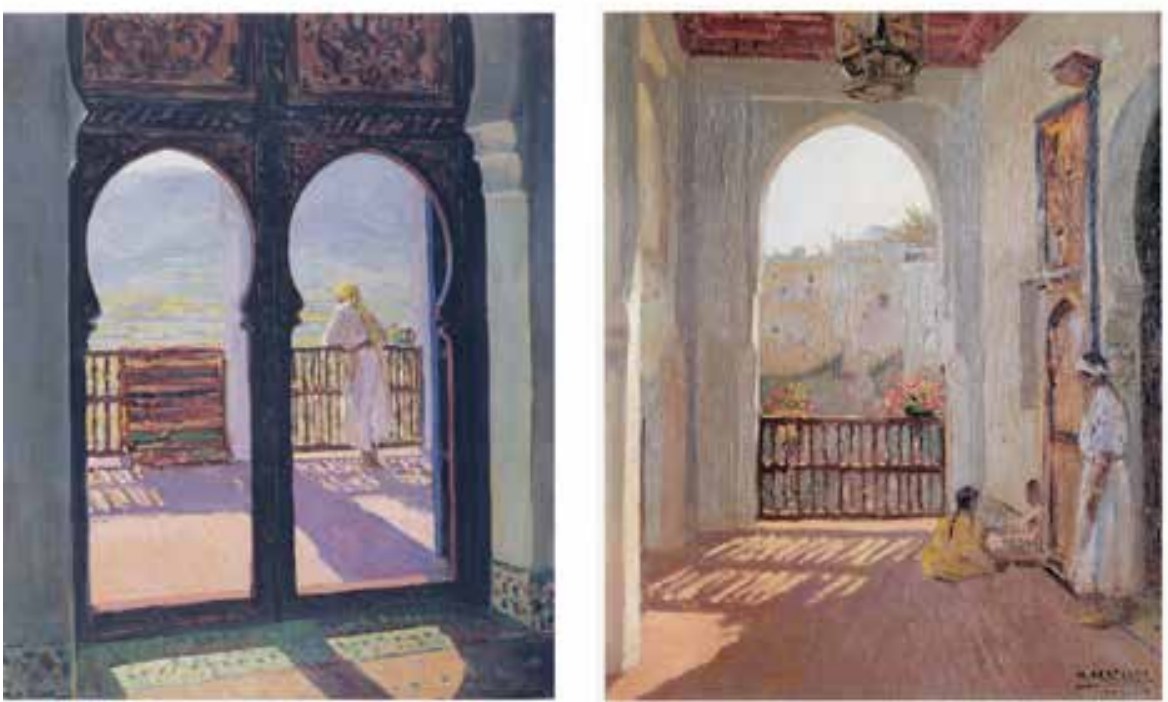

Figs. 5 y 6 .

En la lejanía, se divisa el violáceo y verdoso cortinaje del paisaje montañoso tetuaní, donde el sol resplandece, mientras en la galería parece percibirse el frescor de la sombra detrás del amplio arco árabe de la puerta. Los dos espacios sucesivos, interior y exterior, se comunican a través del gran primer plano vertical de la puerta de entrada, generando un curioso juego de perspectivas y de contrastes tonales, que constituyen una verdadera sinfonía de matices. Fue precisamente en la citada Escuela de Artes y Oficios de Tetuán donde Bertuchi instaló su estudio. Venero describe el estudio del pintor como un mágico espacio en el que

un gran arco árabe daba acceso a la sala de delineación y biblioteca particular, amueblada y decorada con exquisito gusto, pasándose luego a una bonita terraza o mirador, bien orientado, con vistas al jardín de la Escuela desde el que se dominaba toda la amplia vega del río Martín y montes cercanos a Tetuán, bellísimo panorama multicolor por el que sentíase visiblemente impresionado. De éste envidiable estudio salieron las mejores y más numerosas obras de Bertuchi, que 
tomó tal cariño a este "su alcázar" del Arte que terminó por pasar en el mismo casi todas las horas del día, incluyendo domingos y días festivos ${ }^{25}$.

El tema del "interior" de la domesticidad como entorno de la figura femenina fue un tema que nuestro autor trató de manera puntual en su corpus. Al menos se pueden citar cinco ejemplos de narraciones pictóricas, aparte de la ya aducida, en las que recrea ese espacio privado donde la mujer marroquí se desenvolvía. Entre los arquetipos de dicha temática se ha de distinguir Niñas jugando en Tetuán ${ }^{26}$ (1942, Fig. 6), óleo sobre tabla (55 x $45 \mathrm{~cm}$.), donde la terraza de la Escuela de Artes y Oficios de Tetuán vuelve a ser el marco elegido. Aquí, dos niñas, bajo la mirada atenta de su cuidadora, se recrean en su juego al cobijo de un sol que persiste en irrumpir en el decorado para sustraerle protagonismo a los personajes.

Otro ejemplo es Casa de campo. Tetuán (1942, Fig. 7), óleo sobre tabla $(65 \times 80 \mathrm{~cm}$.). La casa de campo constituye un escenario al que Bertuchi recurrió en varias ocasiones como modelo. El decorado tetuaní es tomado como pretexto para introducir de nuevo a sus figurantes femeninos $y$ niños que, captados en un momento cualquiera del día, habitan en un característico y luminoso entorno arquitectónico marroquí rodeado de naturaleza. En la misma línea discursiva, el marroquista pintará dos óleos sobre lienzo, fechados en 1945, El jardín de la Escuela. Tetuán (Fig. 8) y Patio marroqui (Fig. 9). En ambos, los patios de las casas representan uno de los tipos de paisajes interiores de Bertuchi, donde la vida de los personajes discurre sosegadamente al son de "una lectura dialogada entre luz

25 Así lo detalla Joaquín Venero Javierre (secretario del pintor) en un documento sin editar y fechar que poseemos gracias a la gentileza de la familia del pintor.

26 Esta pintura, al igual que Casa de campo. Tetuán, formaron parte de la exposición Paisajes y costumbres de Marruecos, que tuvo lugar en las Galerías Layetanas de Barcelona en 1942, coincidiendo con la muestra del Pabellón Marroquí de la FeriaMuestrario Internacional celebrada en la ciudad condal. Paralelamente al evento, el crítico de arte Joaquín Ciervo ofreció la conferencia titulada "El Cielo Marroquí en la Pintura Española desde Fortuny a Bertuchi”, en la que puso de relieve la consonancia entre ambos artistas. La ponencia, que fue editada en Tánger (1943) en una breve publicación, muestra una imagen del cuadro Casa de campo. Tetuán, entre sus páginas. Véase en Joaquín Ciervo, El Cielo Marroquí en la Pintura Española desde Fortuny a Bertuchi, Tánger, Tip. Hispano-Arábiga, 1943, pp. 1-13 (p. 8). 
y sombra plenamente justificada en la obra del artista" ${ }^{27}$, según subraya Vallina. No en vano, Bertuchi "no es por excelencia el pintor de sol marroquí, [sino] que lo es también de la sombra" ${ }^{28}$, al constatar una crítica de arte de la época con motivo de una de las exposiciones del artista en la Zona:

¿Pero y la sombra?... En ella el artista bucea y rebusca siempre con
éxito y en su lobreguez, al parecer vacía, halla siempre las más puras
tonalidades del espectro, que parecían humildemente refugiadas en
los poéticos rincones para no ser arrastradas y expatriadas de la huida
del sol. Bástenle en estos trances para iluminar sus lienzos, a veces los
altos reflejos del sol sobre los blancos torreones, ya el fresco resplan-
dor de algún espeso parral, bienhechor refugio de las horas del zenit,
o bien algún atrevido y contumaz rayo de sol que penetra sobre la
acerada en la oscura callejuela, se posa sobre la blancura lanosa de la
chilabas o los jaiques y rebordean graciosamente los personajes como
un halo de divinidad...
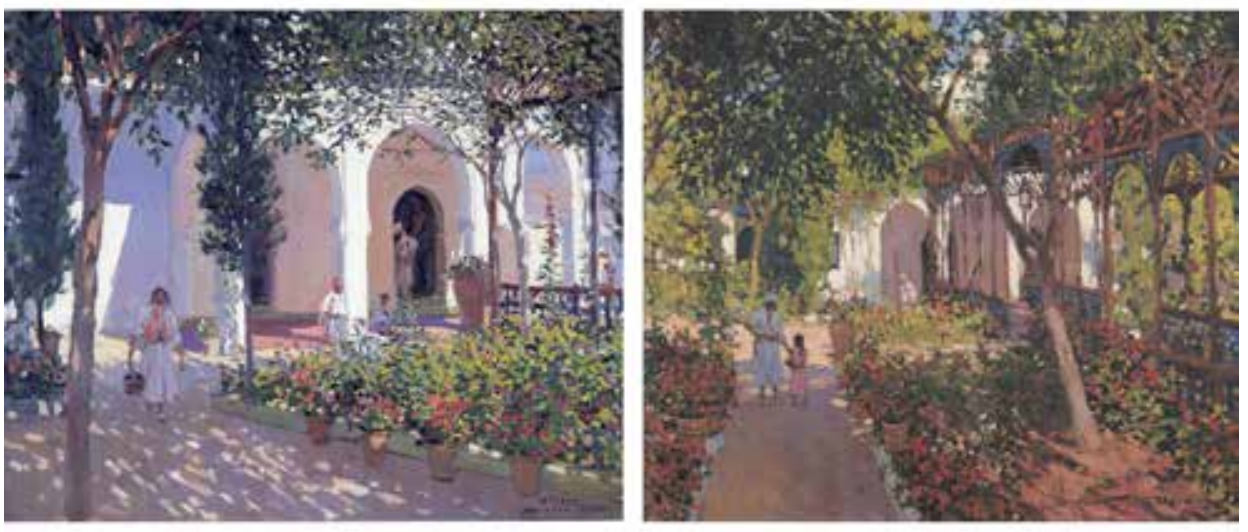

Figs. 7 y 8.

27 Sonsoles Vallina, op. cit., pp. 80-81.

28 Antonio Martín de la Escalera, "Mariano Bertuchi y su labor en Marruecos", Revista de Tropas Coloniales, 15 (1926), pp. 41-43 (pp. 42-43). 


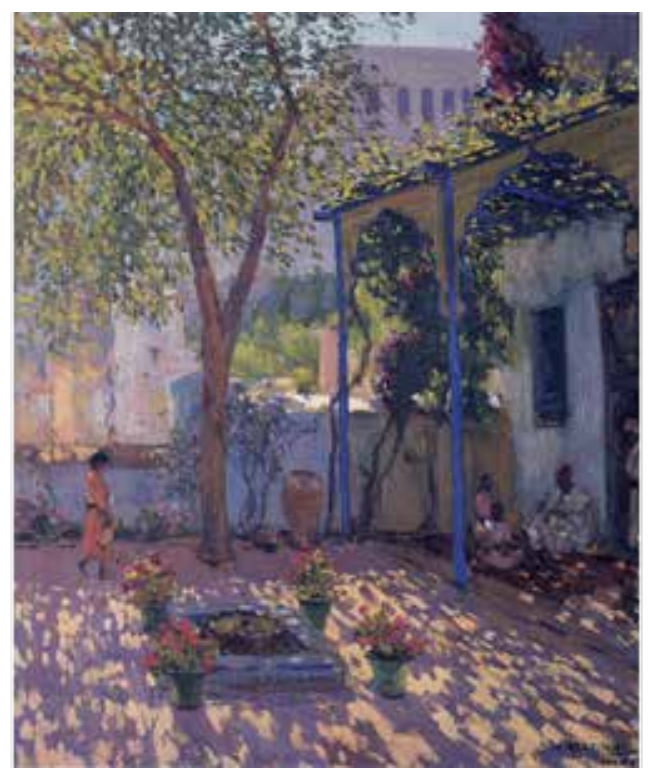

Fig. 9.

De igual modo, Martín Mayor ${ }^{29}$ apuntaría un aspecto interesante, destacando que, a pesar del pertinente y "esquematizador eslogan" atribuido a Bertuchi por la crítica especializada, éste adolece de envergadura como síntesis de toda su pintura:

Se ha comentado hasta la saciedad que es el pintor del sol africano, mojando sus pinceles en la cruda luz del Magreb. Tal afirmación contiene tan sólo una hermosa verdad parcial, porque Bertuchi es un pintor de todas las horas marroquíes.

Pero esa "espacialidad luminosa", esa tonalidad lumínica que domina los decorados pictóricos, a pesar de su presencia dominante, se halla siempre al servicio del color en la producción bertuchiana. El color se transforma en el juego de las armonías y de las asociaciones de tonos, contribuyendo a la creación de ambientes luministas, nunca para que en los valores

29 Antonio Martín Mayor, "Perfiles de Bertuchi a contraluz de Marruecos", Diario de Africa, Tetuán (1950), p. 3. 
cromáticos se desprenda "un ápice de su íntima intensidad, sino, al contrario: la luz concentrada o difundida, manejada al sabio y confidencial antojo, se pliega a la más exacta matización" ${ }^{30}$.

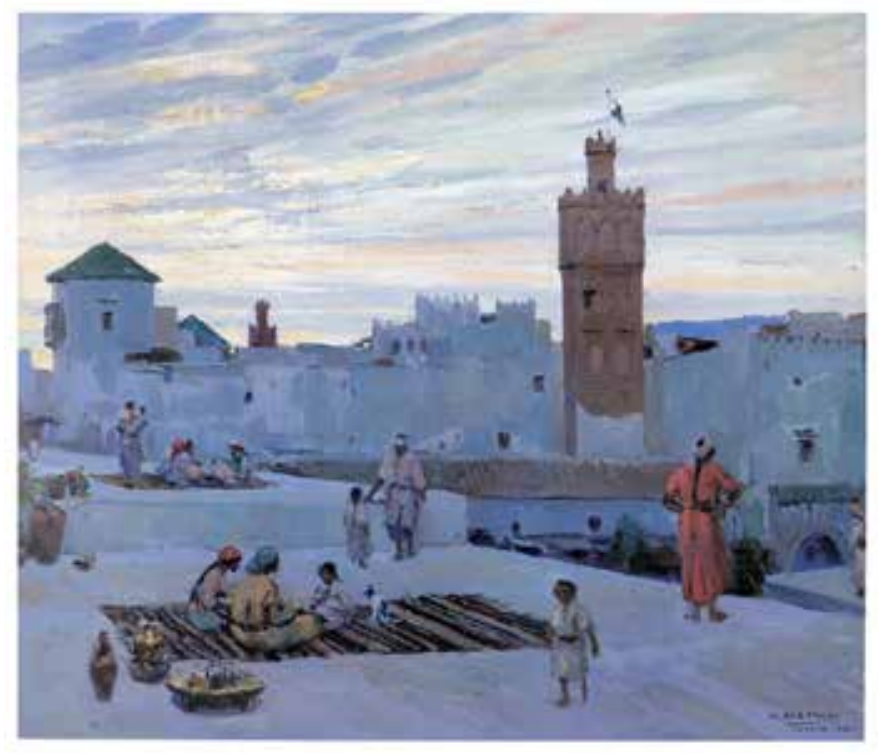

Fig. 10.

Este sucinto análisis del repertorio pictórico bertuchiano concluye con el cuadro Azoteas. Tetuán (1944) (Fig. 10). Sobre un efectista cielo del atardecer tetuaní, que ilumina con múltiples matices azulados las azoteas, éstas se presentan habitadas por grupos de mujeres acompañadas de sus hijos. Desde el escenario de las azoteas se vislumbran el palacio de los $\mathrm{Ba}-$ chauat y el alminar de la mezquita de al-Aayún, transformándose en una especie de harem improvisado donde los personajes conversan, toman el té o contemplan la espectacular puesta de sol.

En un plano paralelo, traspasando las fronteras de la expresión plástica, se descubre una similar representación escénica en el ámbito de la literatura colonial española. Concretamente, en los cuentos escritos por la escritora Carmen Martín de la Escalera ${ }^{31}$ en 1945, reunidos bajo el título de

30 Víctor D'Ors, Arquitectura y humanismo, Barcelona, Editorial Labor, 1967, p. 72.

31 Carmen Martín de la Escalera, durante su transitorio periodo como colaboradora en 
Fatma. Cuentos de mujeres marroquies. Dicho volumen sería ilustrado por Mariano Bertuchi, diseñador, a su vez, de la portada (Fig. 11). La autora compila, en esta colección de relatos, una serie de historias propias que poseen como denominador común el protagonismo de la mujer marroquí.

En la búsqueda de las interrelaciones de ambas manifestaciones artísticas, la visual y la literaria, se revela con cierta fascinación la presencia de sutiles vínculos entre ellas. El decorado de las azoteas tetuaníes del cuadro pintado por Bertuchi, podría ser la transcripción visual de algunos de los pasajes descritos por la escritora. Así, en el capítulo titulado "El corazón que hablaba", puede apreciarse una azotea equivalente a la atalaya pictórica bertuchiana:

Una tarde de otońo suavemente prendida en el cielo luminoso de un azul pálido, descolorido por la intensidad del sol, subimos a la azotea después que Iasmina hubo recomendado a la servidumbre no abrir la puerta, llamara quien llamara. [...]

La mujer marroquí goza quizás como ninguna en el mundo la alegría de recibir el sol en pleno rostro, de respirar libremente, de dejarse vivir al hilo de las horas en una quietud que amodorra el pensamiento, apacigua el sentir y parece anticiparse a la beatitud de los eternos deleites. Contemplando la serenidad con que suelen permanecer horas y horas sentadas en el suelo, puntos perdidos en la claridad blanquecina de las azoteas, sin hablar, sin mirar nada definido, sin reírse, sin entretenerse con una labor, se siente una extraña y compasiva admiración por la humildad de su dicha. [...]

Iasmina, con los ojos entornados por el vivo reflejo del sol que hería las blancas paredes de las casas que por todas partes limitaban el horizonte, se desperezaba en una azalea con blandos movimientos de gata.

Un hondo y vago sopor subía a las tibias azoteas encaladas desde los callejones sombríos donde ningún ruido lograba neutralizar el silencio; caía del cielo como una muda invitación al desprecio de las preocupaciones de la existencia que nos espolea imperiosamente por caminos de inquietud en pos de nuestros inciertos ensueños. ¿Qué más se puede pedir a la vida que sol, paz, cielo, olvido y el tiempo que se estanca? ${ }^{32}$

la revista África, discurrió sobre el papel desempeñado por la mujer en la sociedad marroquí. Véase Carmen Martín de la Escalera, "La madre y el niño", África, 17 (1943), pp. 31-32; y “La mujer marroquí en el hogar”, África, 19-20 (1943), pp. 69-70.

32 Carmen Martín de la Escalera, Fatma. Cuentos de mujeres marroquies, Madrid, Ins- 

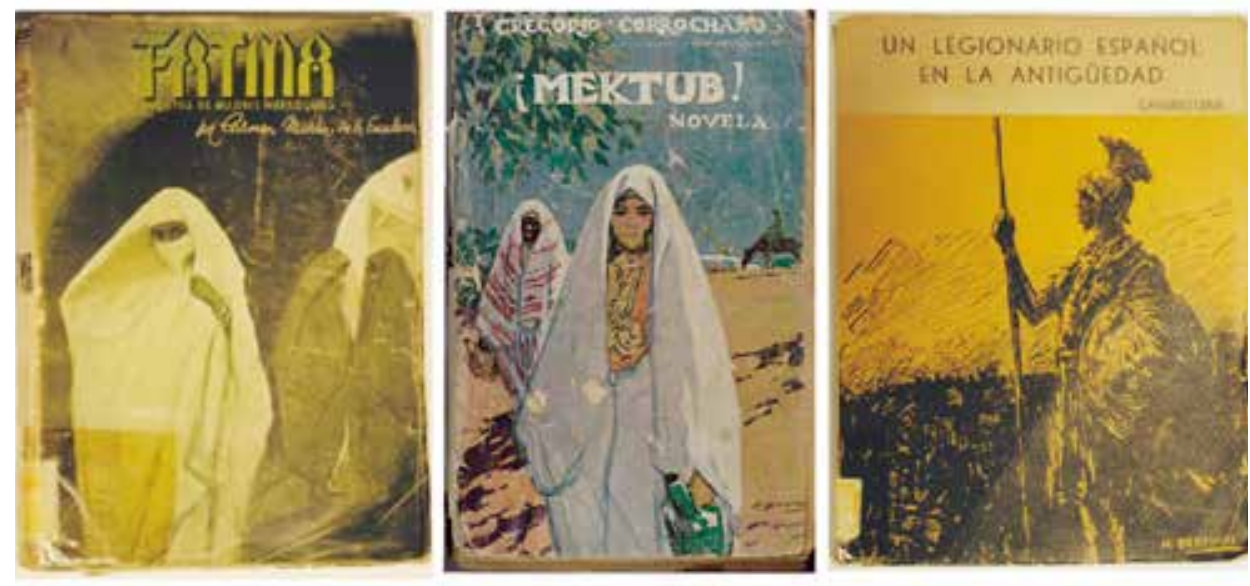

Figs. 11, 12 y 13.

No obstante, ésta no será la única contribución del diseñador africanista como ilustrador en el ámbito de las letras. Residiendo ya en Tetuán, la capital del Protectorado, se destacan algunas colaboraciones como i $\mathrm{Me-}$ ktub! (1926, Fig. 12), para Gregorio Corrochano; Gallofas Moriegas, de Antonio Villalba (Ceuta, 1941); Cuentos marroquies, de Enrique Roda Garrido y Ahmed el Hassan Escuri (Larache, 1941); Sonetos y romances en recuerdo de la entrada del Príncipe Muley Hasan en Tánger, de Rafael Duyos (1942); Estudios varios sobre los principales objetos que se conservan en el Museo de Pelayo Quintero Ataurí (Tetuán, 1942); Un legionario español en la Antigüedad, de Cándido Lería Lanzac (Ceuta, 1944, Fig. 13); Ramadán de Paz, de Tomás García Figueras (1946); Marruecos y España: Perfil de una obra (1952); o El Rogui (1949), de Eduardo Maldonado, por citar algunos ejemplos. Estas obras fueron publicadas mayoritariamente por pequeńas editoriales situadas en el territorio del Protectorado espańol en el norte de Marruecos; por tanto, difíciles de localizar fuera de este ámbito geográfico ${ }^{33}$.

De igual modo, su obra pictórica también fue motivo de portadas en

titutos de Estudios Políticos, 1945, pp. 63-83 (pp. 74-75).

33 Emilio Ángel Villanueva Muñoz y Rocío Carolusa González Tirado, "Mariano Bertuchi, diseńador gráfico", Cuadernos del Arte de la Universidad de Granada, 37 (2006), pp. 277-294 (p. 273). 
diversas publicaciones literarias, como la novela ;Mektub! (1926) del escritor Gregorio Corrochano, cuya ilustración está inspirada en el texto del capítulo XV: "La mora del cantarillo". En ella aparecen Zohra (hija del Xerif Ahmed Ben Mohamed el Harraz el Alamy), en primer término, ocupando la totalidad del espacio compositivo. Vestida con un jaique de color blanco y su faz despejada, mirando fijamente al frente, sostiene un cántaro de un neutro color verde; Jaduya, la esclava de Zohra, se sitúa detrás de la protagonista, a su izquierda; y el capitán Santiago, montado a caballo, aparece situado en la lejanía, en el ángulo superior derecho de la composición.

Por otra parte, hay que de esperar casi una década para volver a vislumbrar la representación de las azoteas tetuaníes de Bertuchi en otro formato. En este caso, el soporte filatélico es el elegido por el diseñador para versionar un decorado parejo al mencionado en la pintura. La obra en cuestión es el sello Moras en las azoteas (Figs. 14-15), perteneciente a la serie "Tipos indígenas", editada el 15 de marzo de 1952. Se podría considerar como el primer sello de la filatelia bertuchiana que simboliza visualmente el universo privado de la mujer marroquí.

Moras en las azoteas constituye un excelente testimonio visual de la apertura de la presencia femenina como verdadera protagonista en el discurso filatélico de Bertuchi. Por presencia se indica, como sugiere Valeriano Bozal a propósito de la pintura española de principios del siglo XX, "algo más que el simple «estar» de una figura" 34 . La figura femenina se convierte en el argumento primordial de la narración visual, respondiendo su presencia a un habitar sólido y categórico. En ese espacio escénico, la actividad de la mujer se torna más que anecdótica.

La ilustración del sello, impreso en un tono verde grisáceo, está enmarcada por un pragmático marco en color rojo de alizarina, induciendo a que el punto de atracción visual se dirija hacia el interior de la composición. Tras la retícula, se desarrolla la escena, con la pretensión de no ser otra cosa que el resultado de una mirada cotidiana. En primer plano, destaca la figura femenina sentada sobre la balconada que, con laxitud estatuaria, se erige de perfil, oteando hacia su derecha, en actitud con-

34 Valeriano Bozal, "Las señoritas de Picasso", en Mujeres pintadas. La imagen de la mujer en España. 1890/1914, Madrid, Fundación Cultural Mapfre Vida, 2003, pp. 78-94 (p. 81). 
templativa. Con su rostro al descubierto, engalanada con vestimenta y accesorios reveladores de la feminidad marroquí, dirige su mirada hacia otro espacio, hacia otro universo alejado en el que se desdibujan un grupo de figuras sobre azoteas contiguas. Junto al citado personaje femenino, a su derecha, una sutil figura alzada de niña, a la que el balcón también proporcionará apoyo. La lectura visual de la parcela de balconada finaliza con varios elementos accesorios situados en el ángulo inferior derecho: una maceta y un jarrón, que terminan por sellar la perfecta escenografía del improvisado y silencioso proscenio de la azotea marroquí, la cual parece estar diseñada para la conversación y la mirada.

Tras la balconada, en segundo plano, se divisa un fragmento de la arquitectura escénica de la ciudad — se adivina Tetuán—, sólo interrumpida por la vertical dibujada del alminar, que actúa como centro geométrico de la composición, y por el perfil de las montańas, delimitadas en la lejanía. Las diagonales generadas por la balconada y las montańas trazarán un juego de líneas en zig-zag, interfiriendo en la monótona horizontalidad que hubiera predominado absolutamente en la secuencia, de no ser por esta maniobra compositiva. El formato del sello, apaisado, produce una mayor impresión de las dimensiones y de la profundidad de la azotea, acentuando a su vez la sensación de soledad que transmiten las figuras situadas en el microscópico adminículo constituido por el sello.
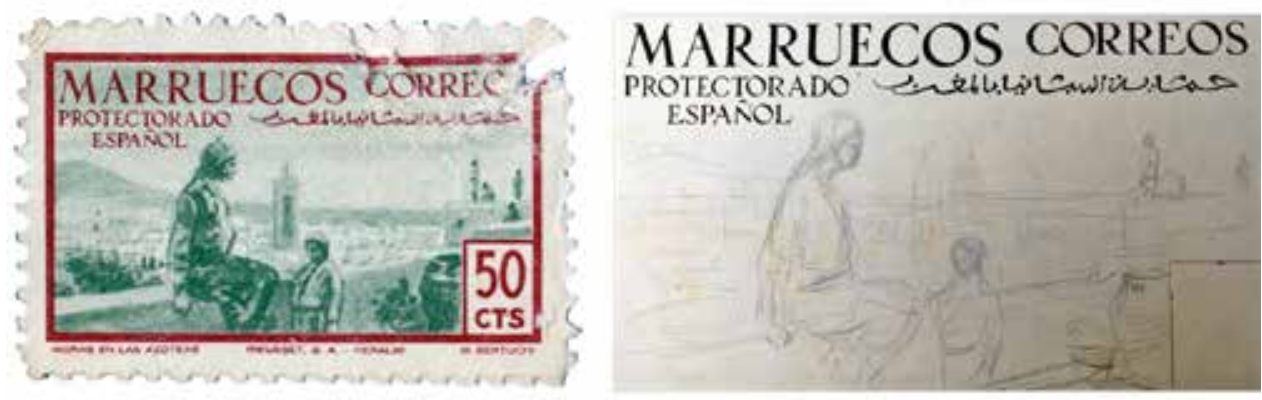

Fig. 14 (izq.). Sello Moras en las azoteas perteneciente a la Serie “Tipos indígenas", 1952. Fig. 15 (dcha.). Boceto a lápiz del sello Moras en las azoteas. Imagen fotográfica (Colecc. J. Abad).

Las figuras de Moras en las azoteas o de cualquier otro título de las obras pictóricas o gráficas citadas podrían corresponderse con alguno de los personajes femeninos, protagonistas o secundarios, de los relatos de Mar- 
tín de la Escalera: Naima, Fatma, Saída, Zubaida, Bechira, etc.; todas ellas, símbolo de la percepción femenina marroquí en la época colonial. Entre todos los cuentos, sobresale el titulado "Un amor triste", cuyos párrafos iniciales, que parecen haber inspirado al pintor, conducen irremediablemente a la imagen implícita en el sello en cuestión:

Se estrellaba el sol contra la deslumbrante claridad de las azoteas encaladas y las lisas paredes de las casas donde mezquinos ventanucos se ahuecaban como ojillos serenos que ni miran ni ven. Las estrechas líneas de sombra pegada al pie de los muros, los surcos negros de callejones y, como gritos de austera pasión, las torres de las mezquitas, cuadradas según exige el rito malekí, constituían el único relieve de aquella masa blancuzca desparramada a flanco de colina como un ramo de lirios caídos en un regazo.

Anulado el detalle por la violencia de la luz, la vega del río Martín confundía los tonos apagados de su escaso arbolado con el ocre verdoso de los campos en barbecho. La masa de los montes de Beni Hassan alzaba sus picos pedragosos de geométricos perfiles duramente sobre el cielo dormido, tranquilo, tenso como un palio de seda azul. Un ligero vaho empañaba sus vertientes, esfumaba las aristas, rellenaba los barrancos.

Naíma sólo veía de este conjunto luminoso el reducido cuadro que podía abarcar desde su azotea: la torre de la Mezquita Mayor, las crestas de los montes, las azoteas contiguas colocadas a distintos niveles donde temblaba blandamente la ropa puesta a secar. Se veían camisas verdes, malvas, azules, rosas, tonos suaves, pastelizados, zaragüelles naranjas, lilas, unos que parecían húmedos, otros descoloridos; edfain ${ }^{35}$ blanquísimos y, con aires de exotismo, algunas prendas de hechura europea ${ }^{36}$.

Es indudable que este documento literario inspiraría a Bertuchi, sugiriéndole un conjunto de imágenes que habrían de materializarse luego de forma plástica. Ambas narraciones, la textual y la visual, se corresponden, de modo que se antoja factible advertir cierta reciprocidad entre los dos medios expresivos. Para Bertuchi, estos antetemas constituyen sólo el

35 El término edfain corresponde al plural de edfin.

36 Carmen Martín de la Escalera, op. cit., pp. 155-199 (p. 155). 
pretexto para concretar el auténtico texto del tema artístico: los paisajes interiores, que se convierten, por la fulgurante magia de unas pinceladas, en la apariencia visual del relato colonial más intimista del pintor.

La atmósfera de silencio que emana de estas secuencias bertuchianas envuelve a las figuras que habitan los espacios privados, enlazando lo cotidiano y lo trascendente, transformando lo natural en simbólico. Los personajes pueden apreciarse de pie o sentados, a veces de perfil o casi vueltos de espaldas, meditando, contemplando, ocupados en tareas domésticas e íntimas o simplemente sin ocuparse de nada, conformando, en su conjunto, la percepción visual de la esencia de la mujer marroquí, en un universo colonial del cual ella es el centro enigmático.
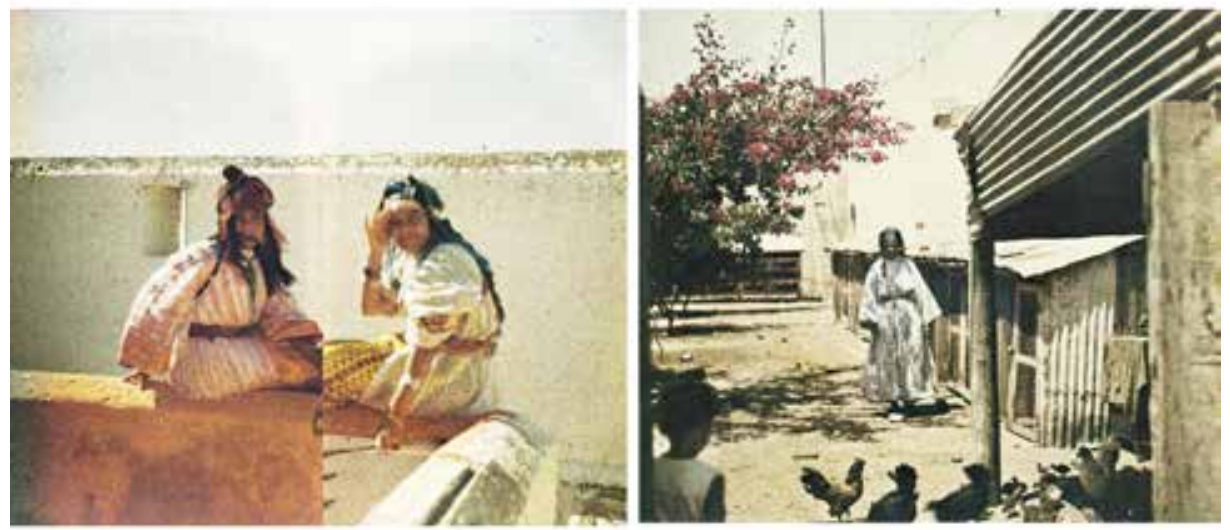

Figs. 17-18. Fotografías estereoscópicas, 1935.

Estos documentos expresivos, más que descripciones costumbristas, pueden considerarse testimonios de una naturaleza simbolista. En este sentido, en sus íntimas escenografías, sumidas en un silencio que parece reflejar estados de ánimo, se aprecia "una doble percepción de la mujer: identificación íntima y distancia insalvable, que no es tan sólo física sino también psicológica" 37 .

Sin embargo, estas desmitificadoras estampas, tan alejadas estéticamente de las transfiguraciones elaboradas por los viajeros románticos europeos

37 Lily Litvak, "El reino interior. La mujer y el inconsciente en la pintura simbolista", en Mujeres pintadas. La imagen de la mujer en España. 1890/1914, Madrid, Fundación Cultural Mafre Vida, 2003, pp. 60-77 (p. 64). 
del siglo XIX, a pesar de destilar cierto aire finisecular, evocando compositivamente pinturas de principios de siglo — como, por ejemplo, $L a$ Terrasa (1891, Fig. 16) de Joaquín Vayreda (1843-1894)—, se aproximan a una percepción sobre la realidad colonial cercana al Marruecos íntimo captado por el medio fotográfico ${ }^{38}$.

En los aludidos paisajes interiores de Bertuchi se advierte un denominador común ${ }^{39}$ que adorna a ciertos elementos ornamentales de sus escenarios tetuaníes. La balaustrada de la terraza, las aristas de las balconadas que separan las contiguas azoteas o los muros que delimitan los luminosos y ajardinados patios de las casas tetuaníes no sólo representan una barrera infranqueable o budud ${ }^{40}$, sino que también se transforman, al igual que La Terrasa de Vayreda, "en metáfora de los límites físicos y psíquicos que, de forma natural, quedaban impuestos a las mujeres" ${ }^{\text {"11. Estas propuestas }}$ estéticas coloniales, delineadas bajo el prisma androcéntrico de un occidental, nos revelan esos cotidianos espacios, privados y acotados, donde la mujer marroquí debía desarrollar su existencia.

38 Por ejemplo, las fotografías pictorialistas de Gabriel Veyre (1871-1936, Figs. 1718) captadas durante su estancia en la corte del sultán Moulay Abd el-Aziz, en Marrakech, a comienzos del siglo XX. Philippe Jacquier, Marion Pranal y Farid Abdelouahba, Dans I 'intimité du Maroc. Photographies de Gabriel Veyre, 1901-1936, Marruecos, Malika Editions, 2012.

39 Este mismo concepto, aunque de una manera aún más simbólica, podría ser también aplicable al sello diseñado por Bertuchi, bajo el título Tetuán (Fig. 21), perteneciente a la serie "Paisajes y monumentos", emitida en 1928. La cartela inferior del sello que compone el marco que encuadra la ilustración servirá de base sobre la que se asiente la protagonista de la escena filatélica, como si se tratara de un balcón improvisado. El marco-bastidor, en este caso, podría compararse metafóricamente con el muro de una imaginaria balconada, cuyas paredes delimitan físicamente a la figura femenina.

40 El término árabe hudud significa frontera. Véase en este sentido el evocador libro de la socióloga marroquí Fátima Mernissi, Sueños en el umbral. Memorias de una niña del harén, Barcelona, Ediciones B, 2013. En él, la autora nos traslada al Marruecos de los años cuarenta durante la Segunda Guerra Mundial y el Protectorado francés, donde a través de sus recuerdos de la infancia evoca la vida cotidiana de las mujeres en una familia tradicional de clase alta en la ciudad de Fez.

41 María López, "Mujeres pintadas: La imagen femenina en el arte espańol de fin de siglo [1890-1914]", en Mujeres pintadas. La imagen de la mujer en España. 1890/1914, pp. 12-47 (p. 14). 


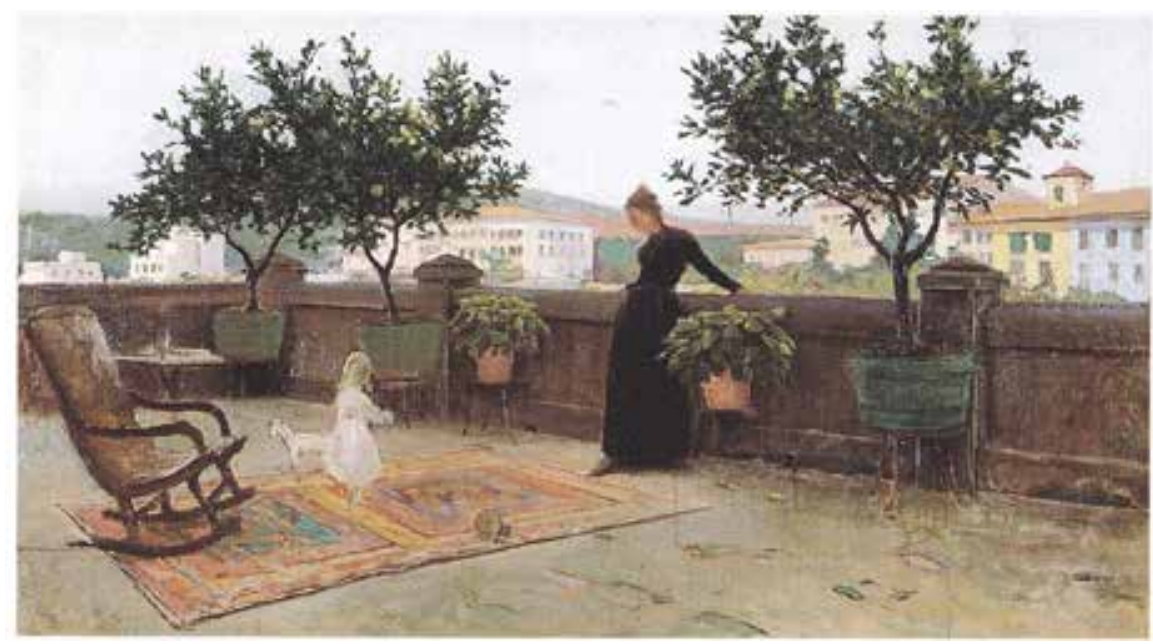

Fig. 16.

Precisamente en el prólogo de los relatos de Martín de la Escalera, firmado por Tomás García Figueras, queda registrada su impresión sobre la evolución social y cultural de la mujer marroquí, apreciando su alcance de un modo conciso:

La evolución de la mujer marroquí, que en sus principios es ciudadana, ha de determinar forzosamente una incorporación más activa de la mujer a la vida social, a costa, naturalmente, de sacrificar el retraimiento en que hoy vive; la mujer marroquí proyectará su vida más hacia afuera y hoy mismo el fenómeno se observa en Marruecos despertando la indignación de los "Viejos turbantes", no obstante de tratarse de una tendencia que es, en su fondo, ortodoxa. Ya en el grupo de mujeres marroquíes que pasean por las ciudades se ve una influencia muy marcada de los gustos europeos, en el vestir, en su afición a los espectáculos, a viajar, etc., que la proyectará también hacia adentro, siendo cada vez más la compañera del hombre, la que llevará al hogar el gusto y el sentido de un vivir, la que colaborará activamente con el padre en la educación de los hijos, la que participará, cada vez más, en la vida espiritual del hombre. Esta evolución ciudadana habrá de ejercer después positiva influencia en la de la mujer campesina ${ }^{42}$.

42 Tomás García Figueras, "Prólogo" a Carmen Martín de la Escalera, Fatma. Cuentos 
La cita es pertinente, pese a su longitud, porque pone de manifiesto una actitud etnocéntrica que no dejaría de impregnar la actuación de España en un territorio, el marroquí, tutelado por el Estado español. Para completar el alegato, García Figueras ofrece otro argumento de las relaciones entre España y Marruecos, contribuyendo al desvanecimiento de la visión deformada que se tenía de Oriente a través "de ese tinte irreal de exotismo y de cosa oriental que ha venido desfigurándolo" ${ }^{43}$ :

Las circunstancias en que ha vivido socialmente la mujer marroquí han tenido forzosamente que influir en su situación actual: encerradas en sus casas árabes, que no miran afuera, sometidas a un régimen riguroso de relaciones sociales, casadas en general muy jóvenes sin conocer, y menos tratar al que ha de ser su esposo; sin ser, en el aspecto en que nuestra sociedad lo comprende, la compañera del hombre, sin posibilidad de formación especial para serlo; sin poder por ello participar en sus afanes y en sus tareas; sin otras distracciones que la limitada expansión de los atardeceres en las altas azoteas, en las que las jóvenes hablan y ríen, y las temporadas campestres en las huertas bellísimas de Tetuán. Es lógico que la mujer marroquí ciudadana haya vivido encerrada en sí misma, en su arreglo, en su vestir, en sus joyas, en sus hijos; es lógico también que hayan pesado sobre ellas las supersticiones, las leyendas fantásticas, oídas en el hogar a las madres, a los parientes de mayor edad, a las esclavas, y que sean exigentes en el rito social de las visitas y de los actos sociales que congregan a las mujeres marroquíes ${ }^{44}$.

Estas líneas reflejan acertadamente la mentalidad del colonizador occidental sobre el colonizado. La relación entre España y Marruecos no debía limitarse a un mero entendimiento, sino que se esperaba, por superestrato, la modificación de las costumbres locales bajo la influencia del poder exterior. En este sentido una de las facetas más importantes, según el autor, habría de ser "la evolución de la mujer marroqui" ${ }^{45}$, o, para ser

de mujeres marroquies, 1945, pp. 11-17 (p. 14).

43 Ibidem, p. 16.

44 Ibidem, pp. 14-15.

45 Ibidem, p. 17. 
exactos, la modificación de las características femeninas de acuerdo con la visión occidental de la mujer.
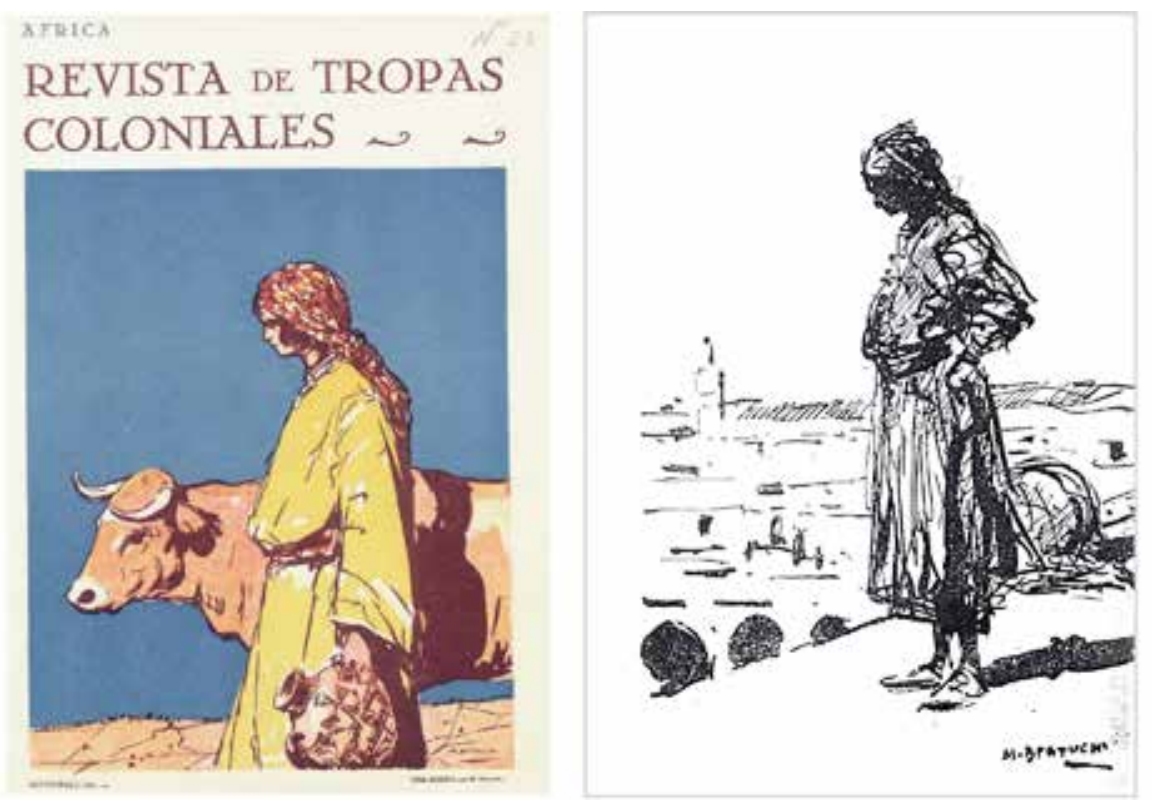

Fig. 19 (dcha.). Ilustración de Mariano Bertuchi para el capítulo titulado "La Cherifa", en Fatma. Cuentos de mujeres marroquies, 1945. Fig. 20 (izq.). África. Revista de Tropa Coloniales (1926).

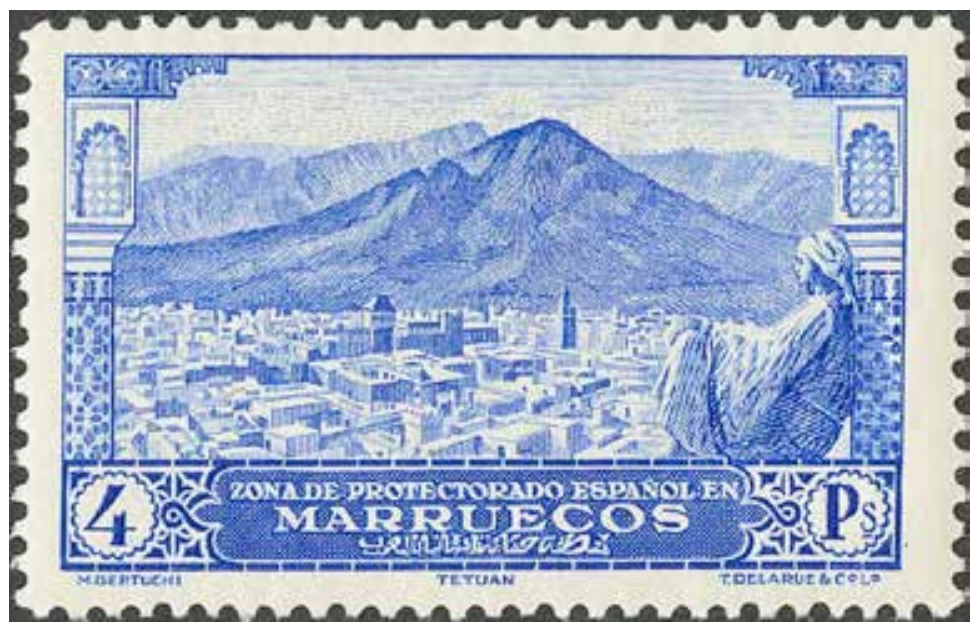

Fig. 21. Sello Tetuán (E117). "Paisajes y monumentos”, 1928. 
Cuando se profundiza en estos fragmentos del archivo plástico bertuchiano, es evidente advertir matices que singularizan el conjunto de las imágenes (Figs. 19-21): la peculiar y elegante silueta de la mujer marroquí reflejada en estas obras, por sus correspondencias formales, responde al mismo arquetipo de mujer. Todas con su rostro descubierto, su cabello recogido con un pańuelo, grandes pendientes en forma de aro, vestidas con idéntica indumentaria, sus característicos y vaporosos edfain y sus inconfundibles babuchas. Resulta curioso percibir como, en este paradigma iconográfico femenino, reaparecen las interrelaciones entre los testimonios artísticos del pintor y los relatos incluidos en Fatma. Cuentos de mujeres marroquies. En el capítulo titulado "Una vida", la descripción de una de sus protagonistas, guarda cierta vinculación estética con las figuras de Bertuchi:
Amina, con la falda recogida, muy liada la cabeza en un pañuelo de gasa, dirigía el trabajo. El ejercicio ponía colores en su rostro mórbido de mujer que rara vez ofrece al sol y al aire puro su cara descubierta, hacía brillar gotitas de sudor en frente estrecha y lisa ${ }^{46}$.

Asimismo, en este capítulo de Fatma. Cuentos de mujeres marroquies se documenta un pasaje con el que es posible rememorar de nuevo no sólo la imagen pintada en La Terraza de Bertuchi, sino también la sucesión de los decorados tetuaníes de las obras citadas con anterioridad, El jardin de la Escuela. Tetuán, Patio marroqui y Casa de campo. Tetuán:

Se encerró en un nostálgico mutismo, la mirada vaga, vacía de expresión, cual si no oyera aquel comadreo sin amenidad.

Aburrida dejó el vaso de té en el suelo y fue a apoyarse a la barandilla que rodeaba la terraza.

El jardín revuelto, sembrado sin método ni preocupaciones artísticas, mostraba sus estrechas avenidas donde la hierba crecía rala por el incesante ir y venir de las gentes, sus rosales medio silvestres abrazados por campanillas, sus chillones geranios que brotaban al azar [...]. Las hojas tiernas de las higueras acharoladas por la luz se inmovilizan en la serenidad de la tarde. Los melocotoneros en flor palidecían sobre el azul intenso del cielo. Por una brecha de la valla se veía la huer-

46 Carmen Martín de la Escalera, op. cit., pp. 85-123 (p. 93). 
ta vecina, solitaria y pobretona, con su jardín sembrado de trigo. [...] -Desde mi jardín — soñó la joven- no se veía nada del exterior. No tenía curiosidad por verlo. ¿Qué me importaba lo que había fuera de mi casa, de mi jardín, del cariño de los míos? ${ }^{47}$.

Estas correspondencias no hacen más que reforzar e intensificar la hipótesis suscitada en nuestras páginas sobre las consonancias entre los relatos escritos por Martín de la Escalera y los poéticos microrrelatos visuales de Mariano Bertuchi.
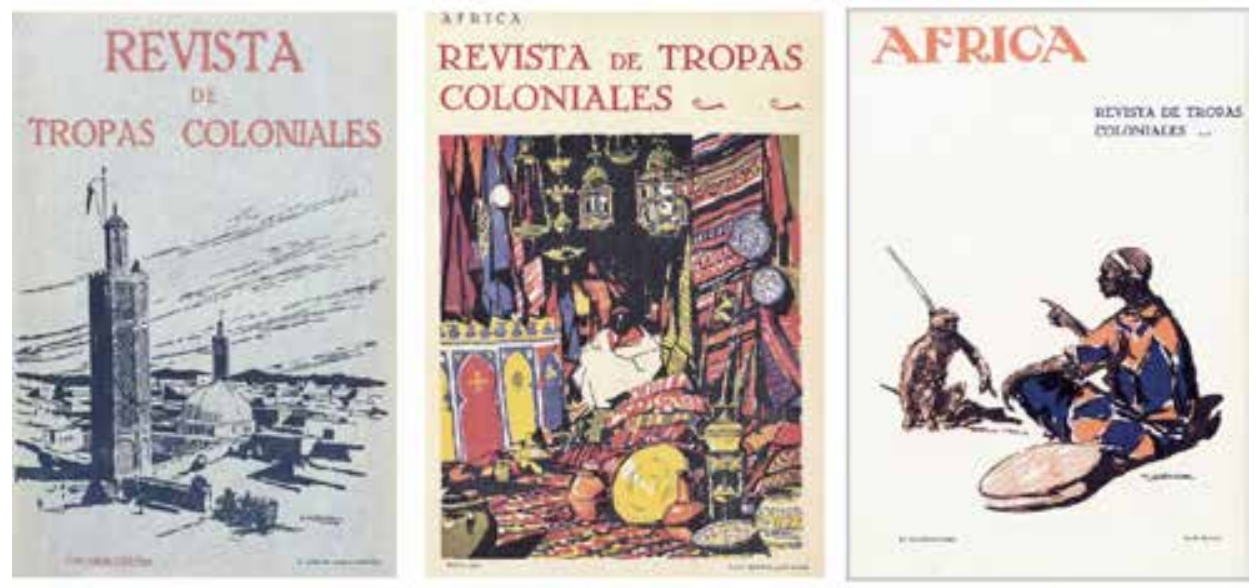

Figs. 22-24

El último modelo femenino podría tratarse, por sus elementos identificativos, de un prototipo de la zona del Rif, que de manera esporádica se aprecia en fotografías que sirvieron de ilustración en África. Revista de Tropas Coloniales. La publicación, una de las más influyentes revistas del colonialismo español, fue el órgano oficial de la Liga Africanista Española en las posesiones en el Norte de África. Para ella, Bertuchi ${ }^{48}$, además de

47 Ibidem, pp. 104-105.

48 La faceta de Bertuchi como ilustrador gráfico es realmente encomiable. De acuerdo con la clasificación que José Antonio Pleguezuelos establece en relación con la obra gráfica de Mariano Bertuchi publicada en diversas revistas de la época, éstas presentan tres etapas bien definidas: una primera fase, que coincide con la edad de oro de la ilustración gráfica, en las primeras décadas del siglo XX, donde colaboró 
confeccionar un considerable número de portadas y una dilatada muestra de ilustraciones gráficas, también ejercería como director artístico (19241928). Entre sus cubiertas, son destacables, por ejemplo, las publicadas en el año 1925, El muecín (Fig. 22), El mendigo y Un mercader; en 1926, Nido de cigüeñas, Vendedores de naranjas, Cuarto Menguante, Las primeras flores, Crisantemos y Bazar moruno (Fig. 23); o ya en 1927, El Saltimbanqui (Fig. 24), Cacharreros y El vado.

Concretamente, se vuelve a localizar a un personaje femenino similar en una ilustración titulada Una Rifeña (Fig. 20) que se utilizó como portada para la citada revista, en su número de septiembre de 1926. Dicha cubierta fue el único diseño de portada para esta publicación compuesto por Bertuchi, y el protagonismo femenino vuelve a resultar absoluto. La estampa se caracteriza por un sintético diseño, en el que destaca en primer plano la figura dominante de mujer con rostro descubierto que, vestida con un luminoso edfin de color amarillo y un pañuelo en tonos rojizos cubriendo sus cabellos, ejerce a modo de eje geométrico en la composición. Tras ella, en segundo plano, la figura de un animal, un ternero, cuya horizontalidad fracciona visualmente la vertical trazada por el cuerpo de la protagonista, que sujeta en su mano izquierda una vasija con decoración marroquí. Ambas figuras contrastan con la minimalista escenografía compuesta por el extenso plano azul de fondo y el escueto fragmento del plano del suelo.

La cerámica que portan las mujeres en los diferentes soportes expresivos, detalle común en las dos ilustraciones de portada aludidas, se convierte en elemento reiterativo en algunas de las obras de Bertuchi analizadas en este contexto, pudiendo percibirse igualmente en una de las imágenes de los sellos de a la serie "Paisajes y monumentos" (1928), en concreto el dedicado a Alhucemas (Fig. 25). La figura femenina ${ }^{49}$, protagonista de la

en revistas gráficas como La Ilustración Española y Americana, Blanco y Negro o La Esfera; una segunda etapa, que tuvo lugar en Ceuta y que coincide con su participación en la Revista de Tropas Coloniales (1924-1927); y por último, un tercer periodo, que desarrolló paralelamente con los cargos de responsabilidad que habría de ejercer en el Protectorado español en Marruecos a partir de 1928, relacionado con revistas y publicaciones de las colonias como África, Mauritania, Marruecos gráfico, Almotamid, Ketama o Marruecos turistico. Véase José Antonio Pleguezuelos Sánchez, Mariano Bertuchi, los colores de la luz, Ceuta, Archivo General, 2013, pp. 160-163. 49 A pesar de los marcos cronológicos equidistantes que separan las secuencias comu- 
escena filatélica, que guarda ciertas concomitancias formales con el modelo de mujer proyectado en las secuencias comunicativas bertuchianas, se halla tras el marco-retícula que conforma el sello, dentro del escenario. En esta ocasión, a diferencia del resto de los decorados, la figura ha traspasado físicamente la frontera representada por el elemento estructural del marco, formando parte ahora del interior del medio escénico junto a los demás actantes ${ }^{50}$. Este detalle, simbólicamente, revela cierta intencionalidad por parte del autor: la mujer se ausenta de sus espacios de silencio, traspasando las fronteras de su entorno privado - ya fuera la balconada, el muro o el marco- - y haciéndose de esta manera visible en un entorno correspondiente a la esfera pública.

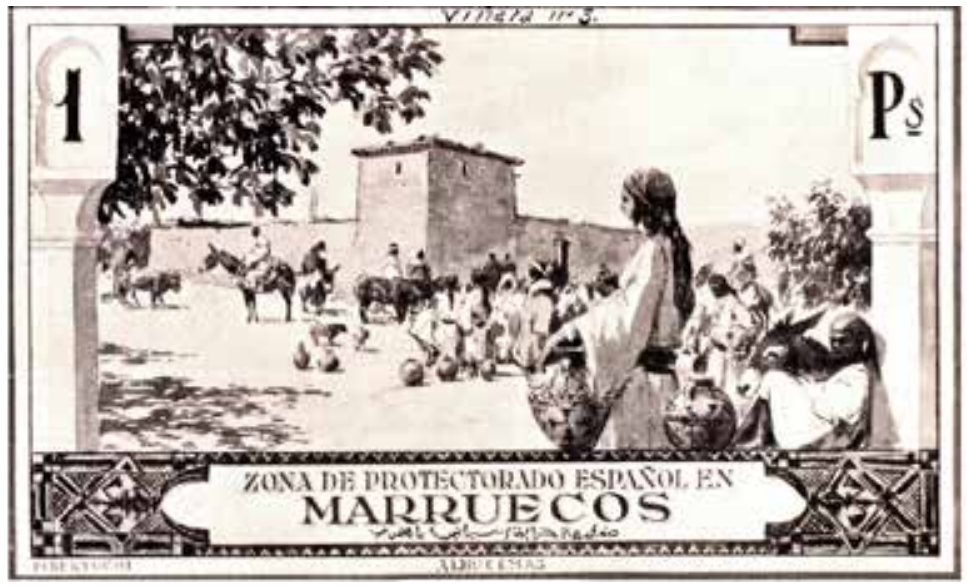

Fig. 25.

\section{Conclusiones}

Este conciso análisis de un fragmento del corpus de Bertuchi revela que el artista puede considerarse un "fotógrafo" de proyecto íntimo, el cual

nicativas analizadas, se advierte que la representación de la mujer marroquí no refleja ninguna variación formal, correspondiéndose con el mismo patrón o estereotipo protagonista dentro de este concreto repertorio iconográfico femenino de Bertuchi. 50 Lorenzo Vilches, op. cit., p. 145. 
supo articular sus instantáneas con el directo de quien capta, cara a cara, lo que estas sienten frente a la sensación de ausencia. Él fue, como sostenía Abad, "un fotógrafo de paisajes interiores y encuentros fortuitos con las cosas que activan la cita de Marcel Proust: «El único verdadero viaje de descubrimiento consiste no en buscar nuevos paisajes, sino en mirar con nuevos ojos»" $"$.

A través de unos breves apuntes biográficos se ha constatado como la predilección de Bertuchi por Marruecos, consecuencia de una fascinación infantil, se tornaría durante su estancia en Tetuán, la capital del Protectorado, en un interés artístico por la captación de una sociedad que estaba siendo colonizada por la cultura occidental, de la que él mismo formaba parte. Su obra no sólo constituye un documento testimonial de la crónica oficial, sino que también es un manifiesto de la existencia cotidiana del pueblo marroquí a lo largo de la primera mitad del siglo XX. Bertuchi reflejó en sus crónicas visuales norteafricanas las connotaciones culturales de los escenarios que lo rodearon. Su proyecto creativo bien podría definirse como un álbum que configuró el imaginario colonial de la Espańa contemporánea.

No obstante, el análisis de esta selección de sus creaciones plásticas permite aseverar que, aunque su obra está asociada indiscutiblemente a un determinado contexto político, su legado artístico trascendió el carácter de mera propaganda del régimen. Para aprehender el justo valor del pintor africanista, resulta obligado mirar con los propios ojos de Bertuchi. Sólo entonces se alcanza a descubrir una dimensión íntima y femenina que excede el ámbito del mensaje oficial que el Protectorado se afanaba en transmitir a través de sus crónicas visuales.

De este modo, se comprende a las claras la conexión entre lo que en este texto se ha denominado los "paisajes interiores" de Bertuchi y los relatos coloniales de Carmen Martín de la Escalera en la década de los Cuarenta. Ambos documentos vienen marcados por el protagonismo de la mujer marroquí. La aportación del pintor al medio expresivo reside precisamente en la captación de dicha privacidad, sorteando, mientras los sublimaba, los límites del decorado colonial. Al contemplar las escenas de Bertuchi, se constata, pues, que lo que el pintor ofrece a los ojos del espectador no es sino la imagen intemporal de la vida humana.

51 José Abad, El Cartel y la Postal, una simbiosis comunicativa en M. Bertuchi: EuropaÁfrica, Tesis Doctoral inédita, Sevilla, Universidad de Sevilla, 1999, p. 29. 